\title{
Corporate Social Responsibility via Shareholders' Proposals
}

\author{
Maria Paz Godoy Uson*
}

\section{Introduction}

Under the American Rule 14a-8 of the Securities Exchange Commission, minority shareholders with a relatively small amount of a company's securities have the opportunity to 'have a say' on significant corporate matters by means of the submission of proposals in the proxy materials. This governance mechanism has become widespread and trendy as it enhances the communication between shareholders and the management, as well as among shareholders themselves. In particular, its popularity has notably increased among social activists, as such rule is an attractive tool for them to achieve corporate social accountability. Consequently, social proposals of shareholders are being considered a useful tool in shifting the strategic direction of companies in a more sustainable direction.

The court case Lovenheim v. Iroquois Brands, Ltd. ${ }^{1}$ illustrates one of the first relevant attempts of shareholder involvement in corporate social policies by means of a shareholders' proposal. ${ }^{2}$ In essence, it deals with the

PhD Fellow Maastricht University.

Lovenheim v. Iroquois Brands, Ltd. (1985) 618 F. Supp. 554 (D.D.C.).

Other attempts of shareholder social proposals were promoted in the 1970s as illustrated in Campaign GM in 1970 and Medical Committee for Human Rights v. SEC in 1972. The first case addressed the efforts of a group known as Campaign GM in requiring General Motors' management by means of several social proposals, crash test specifications, vehicle pollution standards, automobile warranties, mass transit and minority group employment. Campaign GM generated substantial public interest and demonstrated that social proposals have proven to be a viable tool in the battle against corporate irresponsibility. See Schwartz 2012. Two years later, Medical Committee for Human Rights v. Sec (432 F.2d 659 D.C. Cir. 1970) opened the debate on corporate democracy foundations concerning shareholders. Medical Committee for Human Rights, shareholder of Dow Chemical Company, wanted to include a proposal recommending ceasing the manufacturing of napalm (aluminium soap made of naphthenic and palmitic acids used in warfare) used during the Vietnam conflict. The product was developed in cooperation with the US Army. Dow Chemical Company declined the inclusion of the proposal based on the exclusion that was promoting 'general economic, political, racial, religious, social or similar causes' and that it was dealing with a 'matter relating to the conduct of the ordinary business operations'. The SEC considered that such inclusion was in accordance with Rule 14a-8. However the court held that the determination by the SEC was reviewable as there was no basis for the exclusion based - among other reasons - on which the foundations of Rule $14 a-8$ relied on the philosophy of 'corporate democracy'. See "Liberalizing Rule 14a-8 Liberalizing SEC Rule 14a-8 Through the Use of Advisory Proposals", 80 The Yale Law Journal 4, 1971, pp. 845-864 and O'Brien 1984. empowerment of a minority shareholder voicing his concern about a social issue and confirms that the integration of social policies within large public corporations is not exclusively the domain of management. Minority shareholders can foster such a task as well.

Is it possible for minority shareholders to pressure the management to use the company's assets in a more socially responsible but likely less profitable manner? This paper analyzes the chances for minority shareholders in American large public companies to include proposals in the company's proxy materials with the aim to question the current corporate policy. Additionally, it also implies that the increasing submission of social proposals in a country traditionally promoter of a shareholders' primacy model along with the scare activity of shareholders' proposals in Continental European jurisdictions is fostering the process of converge between the main corporate governance models; the shareholder-oriented model and the stakeholder-oriented model, respectively.

\section{The Social Proposal of Peter Lovenheim}

In 1981, Peter Lovenheim became a minority shareholder of Iroquois Brands, Ltd. (Iroquois). With two hundred shares of common stock, Lovenheim was optimistic about the company's performance in the natural and healthy food market. ${ }^{3}$ A few months later, he realized that the company was distributing gourmet French pâté de foie gras (pâté), the manufacture of which he believed involved a form of animal cruelty consisting of the process of force-feeding geese to enlarge their livers and thus producing a larger quantity of pâté. ${ }^{4}$

Lovenheim decided to take action and submitted a shareholders' proxy proposal ruled under Section 14a-8 in the Securities Exchange Act of 1934 (Rule), to be included in the company's proxy material in advance of

Telman 2012, pp. 291-339.

"Force-feeding usually begins when the geese are four months old. On some farms where feeding is mechanized, the bird's body and wings are placed in a metal brace and its neck is stretched. Through a funnel inserted 10-12 inches down the throat of the goose, a machine pumps up to 400 grams of corn-based mash into its stomach. An elastic band around the goose's throat prevents regurgitation. When feeding is manual, a handler uses a funnel and stick to force the mash down..." See Lovenheim V. Iroquois Brands, Ltd. (1985) 618 F. Supp. 554 (D.D.C.). 
the annual shareholders' meeting to be held in May 1983. ${ }^{5}$ The proposal consisted of a request for the company to investigate the process of producing the pâté and, thereafter, inform the shareholders of the outcomes through expert consultation by means of a special committee. The report was meant to conclude whether the production involved a type of animal cruelty and, if this was the case, to determine whether or not the continued distribution of the product should cease until a more humane production method was implemented. ${ }^{6}$

As the control over ordinary business operations has always been part of managers' discretion in the United States (US), in that time, for an individual minority shareholder, it seemed almost impossible to directly request the discontinuity of the product, ${ }^{7}$ nor would it have been possible to accuse the company of distributing a product which was produced with the involvement of a form of animal cruelty. Such type of action could have been seen as a general political demand. Instead, the proponent asked the company to take notice, by means of a special committee, of the likely infringements in the production of one of its products that presumably involved forms of animal cruelty. ${ }^{8}$ This strategy was good and, if the proposal would be accepted, the internal committee would likely prove that there was a social issue involved.

In Lovenheim's first attempt, Iroquois included the proposal in the proxy materials, but the management, firmly resistant, recommended voting against it, as the product represented a small percentage of the company's business. ${ }^{9}$ Lovenheim was, however, able to gather over 5 percent of the casting votes, which he considered a good result, and decided to pursue a second attempt. Yet a few months later, the Securities Exchange Commission (SEC) revised the Rule and added new provisions of eligibility and exclusion, a revision, which was interpreted as a restriction in detriment of the shareholders to access the proxy materials. ${ }^{10}$

The new eligibility provisions required the proponent to hold at least 1 percent or $\$ 1,000$ worth of the corporation's stock and to have held it for at least one year prior to submitting the proposal. Moreover, the new provisions would exclude those proposals relating to business operations, which accounted for less than 5 percent of the issuer's total assets and for less than 5 percent of net

5. Telman 2012. At the moment, Lovenheim became a minority shareholder of Iroquois; he was the Government Relations Counsel for the Human Society of the US in Washington, DC.

6. Ibid.

7. In that time, the proponent did not afford sufficient resources for a proxy war threat.

8. Telman 2012

9. Ibid. Iroquois management gave the following reasons for its opposition: "(1) Iroquois exercised no control over the production of the French pâté; (2) the product is tested and approved by the Federal Food and Drug Administration (FDA); (3) it is unnecessary to form a panel of directors to study an issue over which the board has no control; and (4) the product in question 'represents an infinitely small percent of Iroquois' sale and profits' - in fact the expert consultation called for in the proposal would entail costs in excess of the expected profitability of the product."

10. Lazaroff 1997, pp. 33 earnings and gross sales and were not otherwise significantly related to the issuer's business. With this opportunity, Iroquois, supported by a 'no action letter'11 issued by the SEC, opposed to the social requirement for approval in the forthcoming shareholders' meeting. Lovenheim went to court seeking an order to reverse such an action.

Lovenheim v. Iroquois Brands, Ltd. concerned the interpretation of Rule 14a-8(i)(5) based on the economic and social significance given to a particular business. Iroquois excluded the proposal from the proxy materials because the product in question did not satisfy the threshold of Rule 14a-8(i)(5) and its pâté operations were not 'otherwise significantly related' to the business. ${ }^{12}$ The defendant stated that the SEC wanted to add an economic interpretation to the exclusion. ${ }^{13}$ The plaintiff argued that his proposal was significantly related to the firm's business and that the exposed exclusion should not be interpreted as purely economic as other non-economic tests of significance, social or ethical, could also be applicable.

Despite the economic insignificance of the pâté operations, the plaintiff received the requested preliminary injunction relief from the court. ${ }^{14}$ The court concluded that although the SEC had adopted a 5 percent test of economic significance in its last revision, the proposals were to be included notwithstanding 'their failure to reach the specified economic threshold if a significant relationship to the issuer's business was demonstrated on the face of the resolution or supporting statement' ${ }^{15}$ Overall, the court stated that the meaning of 'significantly related' is not limited to economic significance, ${ }^{16}$ meaning that there was room for ethical and social pro-

11. No-action letters are issued by the SEC staff expressing that it will not pursue action against the company if the proposal is omitted.

12. According to the defendant statements, Iroquois in that moment obtained " .... annual revenues of $\$ 141$ million with $\$ 6$ million in annual profits and $\$ 78$ million in assets. In contrast, the pâté sales were just $\$ 79,000$ last year, representing a net loss on pâté sales of $\$ 3,121$. Iroquois was having only $\$ 34,000$ in assets related to pâté. Thus none of the company's net earnings and less than 5 percent of its assets were implicated by Lovenheim's proposal. The levels were obviously far below the 5 percent threshold set forth in the first portion of the exception claimed by Iroquois..." See Lovenheim v. Iroquois Brands, 618 F. Supp. 554, 556 n.2 (D.D.C. 1985) (citing Affidavit of Iroquois' President and Mc Affrey).

13. Lazaroff 1997.

14. Ibid. See also Bainbridge 2008. In relation to the court's decision there were four relevant interpretations: “...(1) the rule itself was ambiguous; (2) the SEC previously had required inclusion of important social policy questions even where less than 1 percent of the firm's assets or earnings were implicated by the question; (3) in adopting the present 5 percent threshold tests, the SEC said proposals falling short of the thresholds still must be included if their significance appeared on the face of the proposal; (4) the earlier Medical Committee decision implied that proposals involving general political and social concerns were acceptable..."

15. 618 F. Supp. 554, 556 n. 2 (D.D.C. 1985)...citing the court opinion based on the Securities Exchange Commission Act Release No. 19,135,47 Fed. 47,420,47,428 (1982).

16. 618 F. Supp. 554,556 n.2 (D.D.C. 1985). 
posals to be submitted even if the economic threshold was not achieved. ${ }^{17}$

\section{The Empowerment of 'Non- Financial' Minority Shareholders}

Lovenheim v. Iroquois Brands, Ltd. is an early case based on the power that shareholders can exert on managerial decisions for the incorporation of social policies. Likewise, the case implies the shift from the figure of the individual shareholder activist into the institutional one. ${ }^{18}$ Lovenheim acting on his own, but also on behalf of the Humane Society of the United States, was at that time an individual investor facing all the difficulties of a controversial shareholders' proposal mechanism. ${ }^{19}$

\subsection{From Social Proponent to Social Activist}

Even though Lovenheim's proposal was finally admitted to be included in the proxy materials, he only received the support of less than 8 percent of the casting votes. The result was insufficient to convince the shareholders' meeting to approve examining the existence of any form of animal cruelty within the pâté production. This raises the question of whether or not Lovenheim's action was ultimately a failure. In a certain way, it was a failure, as it did not convince the shareholders' meeting or the managers, to examine the geese-feeding process. However, it is worth noting that after the court decision, Iroquois sold the pâté unit, exemplifying a change in the business direction. Thus, the Rule served as an effective mechanism for influencing managerial decisions. Indeed, it was not that relevant that the company never assigned funds and time to examining the social issue, nor it incorporated new social policies within its operations. Just the decision to divest the questioned unit in itself was a clear indication of the empowerment of a minority shareholder achieving its goal. After Lovenheim's court decision, there was a new legal precedent confirming the empowerment of minority 'social' shareholders via proxy solicitations.

Peter Lovenheim became a social activist. Social proposals of a shareholder may easily result in corporate activism. This type of activism basically arises from

17. Ibid. The social and ethical significance of the court decision was supported in the humane treatment of animals as among the foundations of western culture and cites, the Seven Laws of Noah, an animal protection statute enacted by the Massachusetts Bay Colony in 1641, numerous federal statutes enacted since 1877, and animal protection laws existing in all 50 states and the District of Columbia. Additional support was found in leading organizations in the field of animal care as the American Society for the Prevention of Cruelty to Animals and the Humane Society of the United States for measures aimed at discontinuing use of force-feeding.

18. Telman 2012

19. Lazaroff 1997. shareholders' expectations of social result. ${ }^{20}$ Contemporary literature on corporate social responsibility issues regards shareholders' proposals as tools of activism. ${ }^{21}$ Typically they are associated with the claims of minority shareholders and the expression of 'shareholder democracy $^{\prime 22}$ within large public corporations. Social activists tend to be motivated by social reform and, therefore, seek changes to corporate policies. The economic power and visibility of companies are good reasons for pursuing social changes by means of corporate activism. ${ }^{23}$ In common practice, activist shareholders are, for example, interested in the disclosure of the environmental files of the company, the term of contracts with suppliers, the employment of child labour and the end of testing products on animals. In addition to this, they will organize media campaign for better results. ${ }^{24}$

\subsection{Shaping a Long-Term Corporate Strategy}

It has been stated that minority shareholders in public firms do not have enough power to influence the management in pursuing changes on corporate policies. ${ }^{25}$ Corporate law provisions of most jurisdictions grant the authority over corporate affairs to the board of directors and its hired officers who also served for the protection of minority shareholders' interests. ${ }^{26}$ However, the influence of shareholders over managerial decisions has been notably increasing as investors decided to take an active position towards social, environmental and governance issues. ${ }^{27}$ Non-financial performance has targeted corporate boardrooms more than ever as investors believe that environmental and social issues can have a significant impact on shareholder value on a long-term basis. ${ }^{28}$ Currently, this battle is being fought by activist institutional investors, who are in a better position to pursue new corporate directions than dispersed individual investors. ${ }^{29}$

Institutional investors, in defending their financial interests, pursue corporate activism, so it is questionable why they would be interested in pursuing social changes. For those who are not social activists per se, the impact of sustainable development within businesses has led shareholders to take notice of the claims of all the

20. Amann et al. 2007: "...activism includes all actions and procedures undertaken by one (or several) characteristics of the firm in order to better respond to his or their financial, social or ethical expectations... activism is the expression of a governance mechanism used by companies which allows all shareholders to express their voice in numerous domains regardless of their participation in the capital..."

21. Ibid

22. Sutherland 2011: “....shareholder democracy relates the ability of shareholders to influence or determine the course of business..."

23. Tkac 2006

24. Amann et al. 2007.

25. Anabtawi \& Stout 2008

26. Armour, Hansmann \& Kraakman 2009.

27. Posted by Hirts 2011.

28. E\&Y shareholders' press boards on social and environmental risks in $<w w w . e y . c o m / U S / e n / S e r v i c e s / S p e c i a l t y-S e r v i c e s / C l i m a t e-C h a n g e-a n d$ -Sustainability-Services/Shareholders-press-boards-on-social-and-envi ronmental-risks---Is-your-company-prepared-> (last accessed 21 April 2015).

29. Lovenheim v. Iroquois Brands, Ltd. was one of the last relevant cases to involve the participation of a single investor. 
other stakeholders. Such attention to environmental and social issues is seen as a protective device to avoid any potential financial harm, which may be caused by stakeholders' complaints. ${ }^{30}$ The awareness of such issues is allegedly driven by the possible negative impact on financial returns rather than by any ethical reasons. ${ }^{31}$ Additionally, a social policy resolution could likely lead to better financial results within the company. Even more, companies that are underperforming in corporate social responsibility issues can be at greater risk from adverse regulatory or legislative actions, or judicial decisions. ${ }^{32}$

Concurrently, socially responsible investments (SRI) emerged to compensate the inefficiencies of corporate law towards companies' social performance. Social investors aim to enhance non-financial values within companies such as human rights, labour standards, environmental issues and ethical concerns. ${ }^{33}$ Basically, they believe that companies have the power and responsibility to operate for the benefit of others. ${ }^{34}$ The inclusion of non-financial criteria into their portfolios is essential in achieving long-term investment returns. The United Nations Principles for Responsible Investment $^{35}$ and the Carbon Disclosure Project ${ }^{36}$ are just few examples that prove the rising number of investors committed to take a sustainable view towards businesses. ${ }^{37}$ Additionally, the creation of 'Benefit Corporations' and 'B Corps' has boosted a market-based solution to short termism. $^{38}$ This new legal form of companies pursues profits while also considering benefits to society. ${ }^{39} \mathrm{Com}-$ panies with benefits have an explicit social or environmental goal, and give shareholders' additional rights to hold the board and managers accountable for the interests of multiple stakeholders. ${ }^{40}$

A social issue can firmly impact companies' risk management and financial performance. The message for directors is clear: a company's social and environmental policies correlate strongly with its risk management strategy and ultimately its financial performance. ${ }^{41}$ Accordingly, directors should address social issues with particular attention in lieu to reduce potential liabilities. For example, a useful tool is to count with due diligence processes that assess and reduce corporate involvement in human rights abuse. ${ }^{42}$ Thereby, boards can be shielded against mismanagement claims originated by shareholders.

In Lovenheim v. Iroquois Brands, Ltd., it was argued by the company that the examination of a social issue within the company's operations could likely increase its financial costs that would, in turn, end negatively in the decrease of the stock price. It is quite likely that those who voted against Lovenheim's proposal were focusing exclusively on the return of their financial investment in Iroquois. Companies with dispersed stock ownership will, in general, give rise to diverging interests. Probably the majority of uninformed shareholders will vote in consideration to their financial return before expressing

38. Benefit corporations are companies created under American corporate law and should not be confused with 'B Corps,' which refers to companies certified by the NGO B Lab to meet specific standards for social and environmental performance. Companies with benefits have gained the attention of key market players seeking responsible investments. See <www.forbes.com/sites/theyec/2014/05/30/why-consider-a-bene fit-corporation/>. See also <www.economist.com/node/21542432>. Also in <www.huffingtonpost.com/gov-jack-markell/public-benefitcorporation_b_3635752.html>. Benefit corporations are legal creations under US law. Twenty-eight American states have passed benefit corporation legislation. The legal framework de-regulates the purpose of a corporation, giving businesses the additional freedom to consider stakeholders in addition to profit. More information about Benefit Corporations can be seen in <http://benefitcorp.net/>. B Corps are certified by the non-profit company B Lab, to meet rigorous standards of social and environmental performance, accountability, and transparency. Nowadays, there is a growing community of more than 1,000 certified B Corps from 33 countries and over 60 industries. More information about B corps can be seen in <www.bcorporation.net/>.

39. See <www.newyorker.com/magazine/2014/08/04/companies-benefi ts >: " ... Shareholders can sue its directors for not carrying out the company's social mission, just as they can sue directors of traditional companies for violating their fiduciary duty...At a B corp, though, shareholders are just one constituency. Patagonia doesn't need to worry about investors' opposing its environmental work, because that work is simply part of the job...".

40. For B corps "....adopting the B Corp legal framework to expand the definition of the 'best interests' of the corporation should reduce the liability for Directors and Officers by creating legal protection (called 'safe harbor') for them to take into consideration the interests of multiple stakeholders when making decisions, particularly when considering financing and liquidity scenarios. Adopting the B Corp legal framework will, however, give shareholders additional rights to hold Directors and Officers accountable for taking into consideration these same interests when making decisions..."

41. E\&Y shareholders; press boards on social and environmental risks.

42. Sherman \& Lehr 2010. 
their concern on non-financial aspects of the company. The shareholders of Iroquois were not interested to spend time and money in a social aspect that was of insignificant economic relevance for the company.

The adoption of a sustainable or long-term corporate strategy has been reinforced during the last decades, particularly after the appearance of the continual debate concerning the 'goal' of companies. The debate over the corporate goal of companies started in 1932 as a result of the dispute between two corporate scholars, Adolph Berle and Merrick Dodd. The first, co-author of the Modern Corporation, ${ }^{43}$ argued that all powers granted to the management are at all times exercisable only for the benefits of the shareholders. Against this view, Dodd claims that the business corporation is an economic institution which has a social service as well as a profitmaking function. ${ }^{44}$ The question was whether companies should focus in maximizing shareholders' wealth or if there was a broader social purpose that also served the interests of stakeholders like customers and employees and even the society as a whole.

Decades later, in 1970, Milton Friedman's article in the New York Times Magazine ${ }^{45}$ received much attention from scholars and the public. Against the idea of a broader social purpose of companies, the scholar stated that "the social responsibility of business is to increase its profits". Moreover, during the 1970s, economists from the Chicago School of free market, played an important role to raise the shareholder-primacy thinking among the academia arguing that the proper goal of corporate governance was to make shareholders as wealthy as possible.

By the end of $1990 \mathrm{~s}$, the shareholder wealth maximization was the only proper goal of companies. ${ }^{46}$ However, the decline of this shareholder primacy model was closer than expected. After major business scandals in the beginning of the 21 st century and the financial crisis of 2008, the shareholder primacy view became firmly questioned. ${ }^{47}$ The assumption that companies were 'owned' by shareholders solely interested in the maximization of profits was said to be embedded in economic theories. ${ }^{48}$ Excessive risk taking and accounting frauds were a consequence of the shareholder value maximization. In the US, a country strongly characterized for embracing a shareholder-oriented model, started being questioned for promoting a model that was having no legal support. ${ }^{49}$ The issue of a long-term corporate strategy is that shareholders have different time horizons. Management decisions based exclusively on shareholder value thinking can be profitable on a short-term period but value destroying over a longer period of time. A corporate

43. Berle \& Means 1932. The Modern Corporation and Private Property was written by Adolf Berle and Gardiner Means and published in 1932. Regards the foundations of US corporate law.

44. Berle 1932; Dodd 1932

45. See <http://query.nytimes.com/gst/abstract.html?res=9E05EODA153CE 531A15750C1A96F9C946190D6CF>.

46. Hansmann \& Kraakman 2000

47. Elhauge 2005.

48. Stout 2012

49. Ibid. decision-making strategy that integrates social and environmental elements allows the board to better resolve conflicts among diverging shareholders' interests. For example, some shareholders expect to receive early dividends by the end of the year, others might want to give priority to an investment plan on research and development, and others might be interested in exploring new market opportunities by means of a strategy of diversification. Companies desire to attract investors with longterm horizons rather to cope short-term performance pressures originated from active traders. ${ }^{50}$ Recent studies have demonstrated that 'long-term investors lead to a range of corporate behaviours that increase shareholder value'. ${ }^{51}$ Thus, a long-term corporate strategy should be the path to balance diverging shareholders' interests.

In shareholder-oriented systems there are minimal incentives for shareholders to vote guided by the public interest. The term 'public interest' has little presence in corporate law doctrine. ${ }^{52}$ By contrast in stakeholder-oriented systems the public interest is the foundation of the corporate legitimacy. ${ }^{53}$ It is worth questioning whether Rule $14 \mathrm{a}-8$ should be an incentive to address the notion of public interest in a system highly devoted to the maximization of profits. ${ }^{54}$ When viewing companies as social enterprises, making profits for shareholders must be seen as a tool for enhancing the public interest and not as a goal in itself. ${ }^{55}$ Thereof, the Business Judgement Rule might well serve to incorporate social standards in the corporate direction ${ }^{56}$ as the law provides for managerial discretion to advocate the public interest. ${ }^{57}$ But, if the management is failing to incorporate social policies, it is defensible that responsible shareholders are willing to do so.

It has been argued that when the power to make strategic decisions is fully concentrated in the hands of the management, it seems to correlate with poor production

50. Beyer, Larcker \& Tayan 2014.

51. Harford, Kecskes \& Mansi 2015.

52. Lee 2012.

53. Article. 2:8 of the Dutch Civil Code, the duty to take the interests of others: "Under Dutch law, shareholders - unlike management and supervisory boards - are in principle not required to be guided by the interests of the company and its affiliated enterprise. Shareholders may therefore in principle give priority to their own interests, with due regard for the principles of reasonableness and fairness. Based on these principles, however, larger shareholders are considered to have a certain responsibility towards other parties. Paragraph 9 of the Code's preamble provides: 'The greater the interest which the shareholder has in a company, the greater is his responsibility to the company, the minority shareholders and other stakeholders'."

"Institutional investors in particular are being called upon to accept greater responsibility. Although the Code recognises such investors act primarily in the interest of their ultimate beneficiaries or investors, it also provides that 'they have a responsibility to the ultimate beneficiaries or investors and the companies in which they invest, to decide, in a careful and transparent way, whether they wish to exercise their rights as shareholder in a listed company' (IV.4)."

54. Parkinson 1993

55. Ibid.

56. Stout 2012.

57. Elhauge 2005. The author makes a theoretical explanation on the way management discretion is exercised; which is through moral and social norms. 
beneficing social performance. ${ }^{58}$ Those with an interest in it or affected by it are thus willing to get involved in strategic processes. Moreover, it could be argued that social proposals should serve the public interest in a similar approach, since institutional investors are being called to engage with companies in a long-term perspective. Although this debate is beyond the scope of this paper, it should be noted that in Medical Committee for Human Rights v. Sec ${ }^{59}$ (the first relevant court case dealing with shareholders' social proposals), jointly with Lovenheim v. Iroquois Brands, Ltd., the concept of public interest was considered by the judges as favouring a social cause. Presumably, behind a social shareholders' proposal, the principle of shareholder democracy ${ }^{60}$ converges with social welfare in a manner to assure an effective representation of the public interest in strategic decisions.

\subsection{The Risks of Excessive Shareholder Empowerment}

Shareholders' proposals based on self-interested purposes - different from the interests of the company as a whole - have been addressed in the form of legal standards. For instance, the recent financial crisis permitted to discuss whether institutional investors should be subject to behavioural standards in the same manner as directors. ${ }^{61}$ In that sense, the relation between institutional investors and their engagement with companies on a long-term basis has turned into a legal standard. ${ }^{62}$ Such demand for greater accountability on institutional investors should be aligned with shareholders' proposals regulation. As a result, the shareholders' meeting will be better informed and prepared to vote on a social issue.

58. Branston, Cowling \& Sugden 2006.

59. Lazaroff 1997. In Medical Committee for Human Rights v. Sec one of the shareholders from Dow Chemical Company wanted to include a proposal recommending ceasing the manufacturing of napalm - aluminium soap made of naphthenic and palmitic acids used in warfare which was used during the Vietnam conflict. The product was developed in cooperation with the U.S. Army. Dow declined the inclusion of the proposal based on the exclusion that was promoting 'general economic, political, racial, religious, social or similar causes' and that it was dealing with a 'matter relating to the conduct of the ordinary business operations'. The SEC state that such inclusion was in accordance with Rule 14a-8. However, the court determined that there was no basis for the exclusion based - among other reasons - that the foundations of Rule 14a-8 relied on the philosophy of corporate democracy. For more social proposals see New York City Employees' Retirement System v. American Brands, Inc.; Amalgamated Clothing \& Textile Workers Union v. Wal-Mart Stores, Inc.; and Cracker Barrel court decision on employees discrimination on sexual orientation.

60. Tricker 2012, p. 90: "Advocates of shareholder democracy believe that with the rights of share ownership come corporate governance responsibilities." In such manner, institutional shareholders have the duty to control corporate decisions (which could lead in activism) and engage with the company to improve long-term shareholder value (for instance in the UK this has been enhanced with the introduction of the Stewardship Code in 2010).

61. Frentrop 2012

62. On April of this year the European Commission proposed a Directive on the encouragement of long-term shareholder engagement by institutional investors and asset managers. See <http://ec.europa.eu/ commission_2010-2014/barnier/headlines/news/2014/04/20140409_ en.htm>.
The debate on the amount of power that should be given to shareholders within large public companies is continuing. On the one hand, advocates of shareholder democracy argue that shareholders have a monitoring role regarding corporate activities and that they should have more influence on managerial decisions to increase corporate accountability and discipline management. ${ }^{63}$ But, such claim for major shareholder intervention is based on the improvement of corporate performance and shareholder value. ${ }^{64}$ Nowadays, the biggest concern regards hedge fund activism firmly pursuing changes for the immediate increase of stock market prices. Supporting the doctrine, 'the case for increasing shareholder power' may convert Rule $14 \mathrm{a}-8$ into a double edge sword. Although, recent studies have argued that the intervention of activist hedge funds could serve the long-term interest of companies and shareholders, ${ }^{65}$ some scholars have firmly addressed the critical situation of companies targeted by activist hedge funds pursuing self-serving interests. ${ }^{66}$ Such aggressive form of activism causes adverse effects on the rest of the shareholders, employees, communities and the economy. These effects are recognized in the corporate literature, since it has attributed the negative effects of activism of short-term investors in underperforming companies. The type of shareholder as described will try to pressure the management to take decisions based exclusively on the maximization of profits and leaving any social or environmental policies out of the corporate agenda. ${ }^{67}$ For other scholars, minority shareholders' activism in the form of social proposals could be used to pursue self-serving interests. Shareholders may use their power simply to advance activist causes on social and political topics without taking into account the interests of the company as whole. ${ }^{68}$ As a result shareholders' proposals can leave the company in a disadvantaged position.

As a way to restrain behaviour based on self-interest, some authors, who are firm opponents of shareholder interventions, have recently argued that the Rule should require major disclosure of the proponent's motivations, goals or economic interests, which would lead the shareholders' meeting to take decisions better based on the company's best interests. ${ }^{69}$ Furthermore, as a way to

63. Bebchuk 2005

64. Ibid.

65. Bebchuk, Brav \& Jiang 2015

66. See Lipton 2015; Lipton 2013 “...To avoid becoming a target, companies seek to maximize current earnings at the expense of sound balance sheets, capital investment, research and development and job growth..." Also the author argues that the pressure to boost short-term performance metrics was one of the causes of the 2008 fiscal crisis, “.. shareholder pressure was a contributing cause..." See also Lipton 2015.

67. Tricker 2012.

68. Bainbridge 2015.

69. Ibid. The author in this matters indicates the different types of activists: “... not all shareholder interventions are created equally. Some are legitimately designed to improve corporate efficiency and performance, especially by holding poorly performing boards of directors and top management teams to account. But others are motivated by an activist's belief that he or she has better ideas about how to run the company than the incumbents, which may be true sometimes but often seems dubious. Worse yet, some interventions are intended to advance an activist's agenda that is not shared by other investors." 
guarantee the activism of long-term investors, rather than short-term speculators, it would be advisable to increase the terms of the eligibility requirement up to two years. In accordance with this vision, some scholars have argued that greater power should be given to minority shareholders in large public companies along with greater shareholder responsibility by means of expanding the fiduciary duties traditionally applied to the board of directors. ${ }^{70}$

Particularly, in Lovenheim v. Iroquois Brands, Ltd., the court decision did not mention if the proposal of the plaintiff was influenced by self-interested behaviour. It is, however, unclear whether Lovenheim was genuinely pursuing to address an eventual negative economic impact based on reputational reasons or whether it was simply a good approach to a general social concern. ${ }^{71}$ Moreover, an evaluation based merely on the social significance of the proposal makes it difficult for judges to stand for the best interests of all the key corporate players. In this sense, those shareholders who were purely interested in their financial return from Iroquois (the majority) were neglected by the court. It is thus questionable whether the Rule is meant to protect all shareholders' interests or just a part of them. In that sense, it would be advisable to require fuller disclosure of the proponent's interests when a proposal is filed.

\section{Valuable Tool to Influence Managerial Decision}

Usually after the failure of an informally negotiated process between shareholders and management, the process enters a conflict stage that entails the proposition of resolutions at the general meeting of shareholders. ${ }^{72} \mathrm{By}$ means of the Rule, ${ }^{73}$ shareholders in American public corporations have the right to include their proposals in the corporation's proxy materials ${ }^{74}$ under a particular procedure and eligibility test based on 13 grounds of exclusion. This legal mechanism has been ruled by the SEC since 1934 and was used for the first time in 1942. What is relevant is to convince the board to add the proposal to the agenda in order to be voted in the next annual shareholders' meeting. With the submission of a brief text in the proxy materials, shareholders can require a specific action of the management to be presented and voted on at the next annual or special shareholders' meeting. However, even if the proposal gains a

70. Anabtawi \& Stout 2008. The authors argue that the typical fiduciary duties applicable to directors and officers and to some extent to controlling shareholders should also be applicable to minority shareholders as they can use their empowered status to promote corporate actions that give a personal, material economic benefit to the detriment or exclusion of other shareholders.

71. It the case of Iroquois Brands, the reason to divest the business after all was motivated by economic and reputational reasons.

72. Amann et al. 2007

73. Shareholder Proposal Rule, 17 C.F.R. § 240.14a-8 (2012).

74. Dhir 2006. majority vote, the management is still not obliged to implement it. ${ }^{75}$

The majority of corporate scholars consider a shareholders' proposal under Rule $14 \mathrm{a}-8$ as a valuable tool of corporate governance that is meant to influence managerial decisions. ${ }^{76}$ It is also viewed as a unique mechanism in corporate law, as it provides shareholders with the opportunity to initiate corporate action, ${ }^{77}$ thereby negating the traditional decision-making model in which the board acts and the shareholders mostly react. ${ }^{78}$ Overall, it serves as an effective channel of communication for shareholders ${ }^{79}$ to voice their concerns to the management and other shareholders on the company's financial, governance and social performance. ${ }^{80}$ Shareholder participation, by means of proxy proposals, is a useful and relevant way of mitigating managerial agency problems. ${ }^{81}$ Conversely, as mentioned earlier, it has been questioned whether activists are using the Rule simply for their own self-interests rather than for the best interests of the company. ${ }^{82}$ In addition to this, it has to be said that much of its ineffectiveness is attributed to its mere precatory nature. ${ }^{83}$

There are several requirements with regards to eligibility in order for the proposal to be included in the proxy materials. In general terms, the proponent must have continuously held at least $\$ 2,000$ worth of stock, or 1 percent of the outstanding voting shares, for a period of at least one year before the proposal is submitted. Among other exceptions, the company may exclude the proposal if it relates to operations which accounted for less than 5 percent of its total assets at the end of its most recent fiscal year, for less than 5 percent of its net earnings and gross sales in its most recent fiscal year and if it is not otherwise significantly related to the company's business. ${ }^{84}$ If the company considers that the proposal has failed to meet one or more requirements, the management can request a no-action letter from the SEC, stating that the company is allowed to omit the proposal from the proxy materials.

75. Staff Legal Bulletin No. 14 of the Division of Corporation Finance Publication of CF Staff Legal Bulletin, 13 July 2001: "Rule 14a-8 provides an opportunity for a shareholder owning a relatively small amount of a company's securities to have his or her proposal placed alongside management's proposals in that company's proxy materials for presentation to a vote at an annual or special meeting of shareholders. It has become increasingly popular because it provides an avenue for communication between shareholders and companies, as well as among shareholders themselves..."

76. Renneboog \& Szilagyi 2010; Bebchuk 2005; Dhir 2006; Schwartz \& Weiss 1977.

77. Dhir 2006

78. Bainbridge 2008.

79. Dhir 2006

80. Mueller 1998. See also Rojas 2009

81. Bebchuk 2005.

82. Bainbridge 2015; Anabtawi \& Stout 2008

83. Gillan \& Starks 2000; Levit \& Malenko 2011

84. The management can require the SEC to exclude a proposal on several grounds. For a proposal to pass the eligibility test it cannot; (1) reflect a personal grievance; (2) require the firm to violate state, federal, or international law; (3) relate to operations accounting for less than 5 percent of the firm's assets, sales, and revenue, or; (4) deal with a 'matter relating to the company's ordinary business operations'. 
The administration procedure of the Rule has been particularly contested by activists and has thereby been amended several times over the years. ${ }^{85}$ The administrative application given by the SEC has been contradictory. A lot of confusion has surrounded the content of noaction letters that have been issued, particularly because of the inconsistency in the applicability of the Rule's exceptions and its several amendments. ${ }^{86}$ Such a lack of guidance in respect to eligibility requirements and the proper application of the Rule's exceptions encouraged a vast number of lawsuits, with Lovenheim v. Iroquois Brands, $L t d$. being one of the first.

\subsection{Social Contribution of Rule $14 a-8$}

Originally, social proposals were not considered at all. During the first few years, the SEC excluded proposals made primarily 'for the purpose of promoting general economic, political, racial, religious, social or similar causes'. However, the rise of social causes in the $1960 \mathrm{~s}$ changed the corporate landscape, and shareholders, including activist shareholders, began to question the corporation's role in society. ${ }^{87}$ The corporate activism of the 1970 s was seen as a propaganda war against corporate capitalism, and yet social proposals in that time did not create any fundamental change in the corporate system. ${ }^{88}$ The Rule was basically used as a device by social activists to promote unnecessary struggles between activist shareholders and managers. ${ }^{89}$ The current regulation at that time was damaging the efforts to achieve the democratic participation of shareholders. ${ }^{90}$

The major shift came in 1972. For the first time, a court reviewed certain social aspects of the Rule in Medical Committee for Human Rights v. SEC. ${ }^{91}$ Consequently, in 1976 the SEC allowed the inclusion of social policy proposals in proxy materials. This was after deleting the social cause provision and allowing management to exclude shareholders' proposals if they involved business matters that were mundane in nature, or if the proposal did not involve any substantial policy or other considerations. This meant that managers could no longer exclude proposals with significant policy implications. $^{92}$

It should be noted that shareholder democracy is the foundation of Rule $14 a-8^{93}$ as it is primarily meant to protect shareholders. ${ }^{94}$ As confirmed in the most influential cases on social actions, the Rule is meant to enhance corporate democracy and to improve the course of business in case of management bad performance. ${ }^{95}$

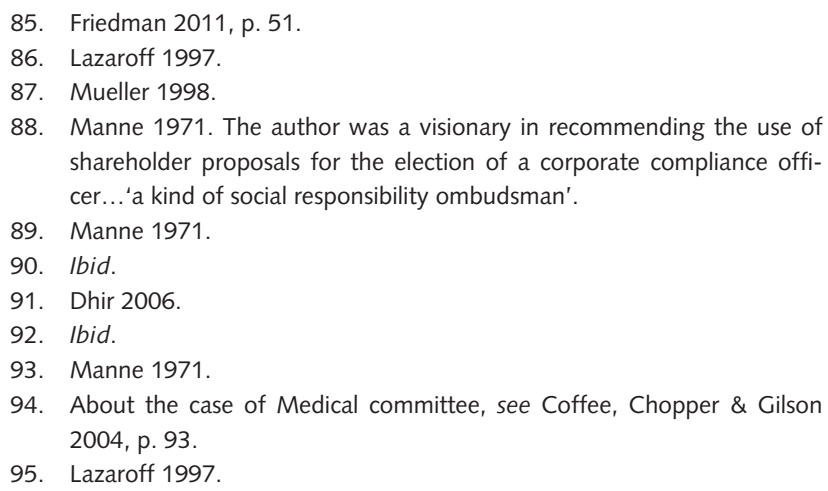

In general terms, the social contribution is given by the fact that shareholders' proposals provide individuals with an opportunity - although not binding - to guarantee the social role of corporations, they foster debate on economic and social issues, and it is likely that they improve managers' decisions. ${ }^{96}$ It must be noted that social proposals for a long time played a subsidiary role towards the American Congress incapacity to rule or act on social topics. ${ }^{97}$ However, such view has changed particularly since the American Congress decided to take action on polemic social issues related with conflict minerals abroad. ${ }^{98}$

Currently, shareholders' social proposals are considered one the most common categories of shareholders' proposals submitted during the last years. According to recent studies, 'shareholders' proposals on environmental and social topics represent 52 percent of all shareholders' proposal submissions so far in 2015, compared to 46 percent in 2014 and 39 percent in 2013.${ }^{99}$ Rooted on Rule $14 a-8$, investors' attention on sustainability practices in the US is on rise.

\subsection{Social Significance of Ordinary Business Matters}

Currently, the debate has led to one of the Rule's exceptions. The ordinary business exclusion has been called the 'most perplexing' of the exclusions. ${ }^{100}$ Proposing recommendations or changes in routine matters is not permitted. ${ }^{101}$ Consequently, Rule $14 a-8(i)(7)$ permits the exclusion from proxy statements of any proposals that are related to ordinary business matters. In other words, recommendations should relate to important policy issues relevant to the company's business. ${ }^{102}$ This entails the task of identifying what is ordinary and what is not, which can be difficult. The SEC has not been clear in defining when a particular issue is not ordinary business and, so it has become a significant matter of

96. Mueller 1998

97. Sachs 2012.

98. According to a report issued by the Congressional Research Service, authored by Michael V. Seitzinger and Kathleen Ann Ruane, 2015, Conflict Minerals and Resource Extraction: Dodd-Frank, SEC Regulations, and Legal Challenge, in relation to the armed conflicts occurring in the Democratic Republic of Congo the American Congress addressed the necessity for transparency of resource extraction payments as follows: “... The Dodd-Frank Wall Street Reform and Consumer Protection Act (Dodd-Frank) added two sections to deal with these issues. Both of the sections require the issuing of regulations by the SEC in order to make public the involvement of U.S. companies in conflict minerals and in resource extraction payments. Very briefly, Section 1502 mandates the SEC to issue rules requiring the disclosure by publicly traded companies of the origins of listed conflict minerals. Section 1504 mandates SEC rules requiring resource extraction issuers to disclose payments made to a foreign government or the federal government for the purpose of the commercial development of oil, natural gas, or minerals. The SEC has issued final rules, and court cases have challenged the rules on several grounds...)..."

99. Posted by Yaron Nili, <http://corpgov.law.harvard.edu/2015/04/28/ shareholder-proposal-landscape/>.

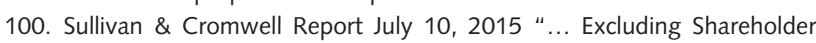
Proposals: Trinity Wall Street $v$. Wal-Mart Stores, Inc." <www.sullcrom. com/siteFiles/Publications/SC_Publication_Excluding_Shareholder_ Proposals_Trinity_Wall_Street_v_Wal_Mart_Stores_Inc.pdf $>$.

101. Friedman 2011.

102. Ibid. 
contestation. ${ }^{103}$ It has been highly complex for the SEC and so on for judges to define the line between ordinary business operations and social policy matters. ${ }^{104}$

Some court cases have illustrated the inconsistency of the SEC in respect to ordinary business matters. In 1991, shareholders of Amalgamated Clothing and Textile Workers Union submitted a proposal to Dayton Hudson Corporation asking to report on equal employment opportunity initiatives. The company excluded the proposal, since employment issues were related to ordinary business matters. The SEC refused to issue a no-action letter, stating that an equal employment opportunity would involve policy decisions beyond those personal matters that constitute the company's ordinary business. One month later, the SEC sided with Wal-Mart Stores, Inc., to exclude an identical proposal submitted once again by Amalgamated Clothing and Textile Workers Union. Although both cases were focussed on the interpretation of the same exclusion, the SEC concluded that in the first case, the proposal should not be excluded, as it was not related to ordinary business matters, while with respect to the second case, the SEC sided with the company. ${ }^{105}$ Another relevant case is dated back in 1992, called Cracker Barrel. Cracker Barrel, a restaurant chain, fired a group of employees based solely on their sexual orientation. One of its shareholders, New York City Employees' Retirement System (NYCERS), submitted a proposal pursuant to Rule $14 \mathrm{a}-8$, requiring the amendment of its non-discriminatory hiring policy statement. The company refused to include such proposal stating that it was related to ordinary business matters. ${ }^{106}$ However, at NYCERS' request, the court reversed the SEC's decision and the proposal was admitted for shareholders' voting. The result was the full incorporation of non-discrimination policies within the company.

These cases show the ability of the Rule to initiate social policies within corporations. Now, the purpose of the current controversial Rule's exception implies that what is 'mundane in nature' should remain within the management's exclusive providence, whereas shareholders are entitled to have a say on those things which constitute significant policy matters. ${ }^{107}$ On this matter, the SEC has confirmed that:

Certain tasks are so fundamental to management's ability to run a company on a day-to-day basis that they could not, as a practical matter, be subject to direct shareholder oversight. Examples include the management of the workforce, such as the hiring, promotion, and termination of employees, decisions on production quality and quantity, and the retention of suppliers. However, proposals relating to such matters but focusing on sufficiently significant social policy issues (e.g., significant discrimination matters)

103. Dhir 2006

104. Sullivan \& Cromwell 2015

105. Dhir 2006.

106. Sachs 2012.

107. Ibid. generally would not be considered to be excludable, because the proposals would transcend the day-today business matters and raise policy issues so significant that it would be appropriate for a shareholder vote. $^{108}$

Notwithstanding, if the SEC promotes shareholders to submit proposals that are related to tobacco products, disclosure of political activities and supply chain environmental issues, it is quite difficult for shareholders to demonstrate that those are not part of the ordinary business activities of the company. ${ }^{109}$ Therefore, the SEC will continue with the case-by-case illustration model and judges are recommended to refer to Lovenheim $v$. Iroquois Brands, Ltd. ${ }^{110}$ The exclusion under Rule $14 \mathrm{a}-8(\mathrm{i})(7)$ should be revised as it has been demonstrated to be ineffective to address social concerns.

One of the most recent actions dealing with shareholders' social proposal was seen in Trinity Wall Street $v$. Wal Mart Stores Inc. Trinity. ${ }^{111}$ An episcopal parish in New York City, submitted a proposal for Wal-Mart's 2014 annual meeting requesting that the Compensation, Nominating and Governance Committee Charter be amended in order to develop and implement standards for use in deciding whether to sell a product that '(1) especially endangers public safety; (2) has the substantial potential to impair the reputation of Wal-Mart and/ or; (3) would reasonably be considered by many offensive to the family and community values integral to the Company's promotion of its brand.' The aim was to pressure the board in order to stop the sell of fire guns. Wal-Mart obtained a 'no-action letter' from the SEC based on the ordinary business exclusion. Trinity decided to go further and filed a suit. The Court supported Trinity's shareholders' proposal considering that it did not deal Wal-Mart's ordinary business operations. Social policy issues, such as the sale of high-capacity firearms, may 'transcend the day-to-day business matters'. According to the Court's decision, Trinity may resubmit its proposal for Wal-Mart's 2015 annual meeting.

However, on 6 July, the US Court of Appeals for the Third Circuit reversed the decision. ${ }^{112}$ According to the Court's opinion, it was argued that the shareholders' proposal relates to ordinary business operations despite the fact that raises a significant social policy issue. The subject matter of the proposal 'targets day-to-day decision-making" and so to excludable from being included in the proxy statements. The court also sustains that Wal-Mart being a retailer of multiple products commands the determination of an appropriate mix of products to the management and to the board of directors.

108. Amendments to Rules on Shareholder Proposals, Exchange Act Release No. 34-40018, 1998 WL 254809.

109. Bainbridge 2015.

110. See Bainbridge 2011.

111. "Third Circuit Provides Guidance on Excluding Shareholder Proposals", posted by Buckholz et al. 2015.

112. Trinity Wall St. v. Wal-Mart Stores, Inc., No. 14-4764 (3d Cir. July 6, 2015). 
By contrast, a decision to stop selling a particular product is more likely to transcend ordinary business matters (like when the company is a manufacturer of a narrow line of products). Wal-Mart is a major retailer and Trinity's proposal addressed how Wal-Mart approaches merchandising decisions and not addressed a formal request to stop selling fire guns.

\subsection{Non-Binding Nature of Rule 14a-8}

As mentioned earlier, the Rule is precatory in its nature. Even if shareholders approve the resolution by more than 50 percent of the votes, the management can decide not to implement it. ${ }^{113}$ Only the proposals that are likely to increase the value of the company, or have strong support from the shareholders, tend to be accepted. ${ }^{114}$ Because of the aforementioned condition, some scholars argue that proposals from shareholders can in no way determine corporate policy, meaning that, as in all corporate law systems, the board is still responsible in running the company. ${ }^{115}$ In addition, the inability of the Rule to change corporate policies has been supported by empirical studies that have evaluated the mechanism as inefficient, ${ }^{116}$ thereby considering it as little more than a simple channel of communication. ${ }^{117}$

Nonetheless, Rule $14 a-8$ is still a very powerful tool for minority shareholders as they can influence managerial decisions even if their proposals do not pass. For instance, social policy proponents are aware of the nonbinding feature of the Rule and its likely unpromising outcomes. In that sense, a social proponent will seek to call attention to an issue in order to obtain legislative or regulatory changes or to influence public attitude more generally, rather than to expect any immediate change in the social policies of the company. ${ }^{118}$ Thus, the goal for a proponent is to obtain enough votes for the proposal in order for it to be re-submitted the following year. ${ }^{119}$ This goal is more like a broader strategy and bears similarities to the one illustrated in Lovenheim $v$. Iroquois Brands, Ltd.

Furthermore, even withdrawn or rejected proposals of the shareholder are viewed as proper governance mechanisms to foster corporate changes. As a means to avoid negative publicity or an adverse vote at the shareholders' meeting, managers frequently invite activist shareholders to negotiate privately before the initiation of a submission. This results into the possibility that the proponent might come to a satisfactory agreement, meaning having the proposal or request fully or partially implemented. ${ }^{120}$ This suggests that private negotiations are an alternative mechanism that should not be underestimated.

\footnotetext{
113. Rojas 2009 .

114. Levit \& Malenko 2011.

115. Thompson \& Edelman 2009. The board authorial power is reinforced with the Business Judgement Rule.

116. Rojas 2009 .

117. Amann et al. 2007: “... these proposals are just meant to inform the management of the various shareholders opinions..."

118. Friedman 2011

119. Ibid.

120. Bauer, Moers \& Viehs 2015
}

Empirical studies have demonstrated that a majority of votes on non-binding proposals of the shareholders have a persuasive effect on managerial decisions. ${ }^{121}$ In 2013, evidence from the proxy access of the largest American companies suggested that environmental and social issues represented the principal category of shareholders' proposals submitted. ${ }^{122}$ Moreover, voting support has notably increased, even reaching the threshold level of 30 percent support, which is seen as sufficient to be considered by the management. ${ }^{123}$ Empirical evidence has also demonstrated that regardless of the precatory nature of shareholders' proposals under the Rule, as many as 40 percent of those proposals which achieve a majority vote are implemented. ${ }^{124}$ Furthermore, directors are strongly pressured to respond the demands of shareholders' proposals. This is caused by the fact that if they receive more than 50 percent of the votes and they fail to respond, they surely will be targeted for removal in the forthcoming year. ${ }^{125}$ In response, one of the two major proxy advisory firms in the US has recommended in its proxy voting policies for the 2014 proxy season to vote against director nominees when the board has failed to act on shareholders' proposals that received the support of a majority of the shares cast in the previous year. ${ }^{126}$ Clearly, the current message for American directors is that shareholders' proposals should not be underestimated as their non-binding status is being diminished.

\section{Shareholders' Social Proposals in the EU}

In contrast to the situation in the US, adopted shareholders' proposals are binding in the UK and in most of Continental European jurisdictions. ${ }^{127}$ The European binding feature of shareholders' proposals should thus encourage greater attempts at influencing corporate direction. However, such is not the case, at least not in Continental Europe, where any activity to submit shareholders' proposals is still rare. Instead of submitting proposals, shareholders prefer to negotiate behind the scenes. ${ }^{128}$ Friendly negotiations are a common practice, especially within countries with large concentration of stock ownership. ${ }^{129}$ Consequently, European sharehold-

121. Renneboog \& Szilagyi 2011.

122. Ernst \& Young Report 2013. The report states that other major proposals are related with board-focused, compensation and anti-takeover strategic proposals.

123. Ibid

124. Cziraki \& Renneboog 2009. For more empirical studies on the effectiveness of shareholders' proposals, see Bizjak \& Marquette 1998; Martin \& Thomas 1999; Thomas \& Cotter 2007; Ertimur, Ferri \& Stubben 2008.

125. E\&Y shareholder press boards on social and environmental risks.

126. See from the Institutional Shareholder Services the 2014 U.S. Proxy Voting Concise Guidelines <www.issgovernance.com/file/files/ISS2014 USConciseGuidelines.pdf>

127. Ibid.

128. Cziraki, Renneboog \& Szilagyi 2009.

129. Amann et al. 2007. 
ers' proposals have not received much attention from corporate law scholars. ${ }^{130}$

\subsection{The Restricted Landscape for Shareholders' Proposals in Europe}

It is notable that even though shareholders in the US must cope with the precatory nature of proposals, they still serve as an advanced model of shareholder engagement and activism. Therefore, it is arguable why shareholders in European companies are so reluctant to submit proposals considering their binding nature. This could partially be explained by the fact that shareholders in European companies may easily call for extraordinary meetings, in contrast to the American-restricted situation. ${ }^{131}$ Therefore, managers in European companies will try to negotiate before reaching the phase of a conflict form by means of the requisition of an extraordinary shareholders' meeting. ${ }^{132}$ Conversely, American shareholders may only have this right if stipulated under the company's articles of association.

Additionally, the ownership structure is another reason to take into consideration for the scare activity on shareholders' proposals in Europe. Deviations from 'oneshare-one-vote' principle, existence of multiple voting, pyramidal structures and cross-ownership structures are common features of most Continental European companies. ${ }^{133}$ Under such corporate structures it is common to resolve differences behind the scenes, particularly when considering that proposals are seen as a negative signal of governance and drivers of a negative stock price effect. ${ }^{134}$ Furthermore, European minority shareholders do not enjoy the level of legal protection that is given in the US. In addition, some Continental European firms still have the multiple classes of shares, thus avoiding the one-share-one vote rule. ${ }^{135}$ It has even been stated that lawsuits may be more effective than the practice of submitting proposals. ${ }^{136}$ In recent years, however, minority shareholders in Germany and the UK have considerably increased their participation by means of corporate activism. ${ }^{137}$

130. Richardson 2012: " "...shareholder advocacy is predominantly a North American tradition and is not as widely practiced among European social investors or in other markets..."

131. Cziraki, Renneboog \& Szilagyi 2009. For instance, in the UK, France, Germany, Norway, the Netherlands, Switzerland and even Russia shareholders, are entitled to put items on the agenda and call for extraordinary meetings. In general, the percentage ownership required to call for an extraordinary meeting and submit a proposal is between 5 and 10 percent. Notably in the Netherlands, the ownership percentage to submit proposals is of 1 percent or share ownership of EUR 50 million of the firm's shares and certificates (depository receipts?). However, in Dutch companies, specific proposals may be exclusively initiated by the board.

132. See Amann 2007, p. 341 about the two forms of relationship between institutional investors and companies.

133. Renneboog \& Szilagyi 2013

134. Cziraki, Renneboog \& Szilagyi 2009: 'likely a controlling shareholder is willing pressure the board so as to friendly negotiate with a dissenting or unhappy minority shareholder. A wise decision is to avoid any intervention during a general or extraordinary shareholders' meeting as it is the best scenario for shareholders' activism' (Amann et al. 2007).

135. Cziraki, Renneboog \& Szilagyi 2009.

136. Girard 2009.

137. Fairfaix 2008
Overall, the impediment for the proliferation of European shareholders' proposals, lies on the diverging regulation concerning proxy submissions across jurisdictions. Recent empirical research on shareholder engagement in European companies conclude that the technical solicitation process entails too many barriers in allowing shareholders to submit proposals. ${ }^{138}$ The fact that in the US shares must be registered makes it easy for shareholders to contact other shareholders. By contrast in most European jurisdictions, ownership is not recorded because of the existence of bearer shares, which of course is seen as a barrier for shareholder engagement. If shareholders where communicated with other shareholders it would be easier for the proponent to gather greater support in order to succeed with the proposal. Equally, it has been demonstrated that high minimum ownership thresholds and the existence of share blocking tend to diminish shareholders' proposals. ${ }^{139}$

European regulatory framework has been especially concern on European shareholders' 'rational apathy'.140 The last revision on the Shareholders Rights Directive (Directive 2007/36/EC) - which aims to encourage long-term shareholder engagement - has slightly addressed one of the above-mentioned barriers. The revision might have been a good opportunity to enhance shareholders' proxy submissions. However, the new text did not took a clear stance towards the encouragement of shareholders' proxy submissions. Exceptionally, the revision took a step forward in creating a 'framework to allow listed companies to identify their shareholders and requiring intermediaries to rapidly transmit information related to shareholders and to facilitate the exercise of shareholder rights'. ${ }^{141}$

There is no strong recognition for encouraging proxy submissions in Europe. Corporate scholars have argued that European countries are not ready to apply the US approach on the governance role of shareholders' proxy submissions. ${ }^{142}$ This is supported with the high five percent minimum ownership requirement. As a result, it is quite difficult for minority shareholders to form coalitions in order to achieve the 5 percent threshold

138. Renneboog \& Szilagyi 2013.

139. Ibid.

140. See <http://ec.europa.eu/internal_market/company/shareholders/inde xa_en.htm>.

141. See new Chapter IA: "Identification of Shareholders, Transmission of Information and facilitation of exercise of shareholders rights". The revision of the Shareholders Rights Directive states that "...the Identification of shareholders has an impact on fundamental rights recognised in particular in the Treaty on the Functioning of the European Union (TFEU) and in the Charter of Fundamental Rights of the European Union (Charter), notably the right to the protection of personal data recognized in Article 16 TFEU and in Article 8 of the Charter. In view of this and of Directive 95/46/EC of the European Parliament and of the Council of 24 October 1995 it is necessary to strike a balance between the facilitation of the exercise of shareholders' rights and the right to privacy and the protection of personal data. The identification information on shareholders is limited to the name and contact details of the corresponding shareholders and can only be used for facilitation of the exercise of shareholder rights..."

142. Cziraki, Renneboog \& Szilagyi 2009. 
basically because of the existence of bearer shares. ${ }^{143} \mathrm{It}$ seems that the revision of the Shareholders Rights Directive intends to avoid situations of excessive shareholders' activism as frequently occurring in the US.

Thereby, it could be argued that the increasing demand of social proposals promoted in the US and the limited activity of European shareholder proposals are precipitating the process of converge between the shareholderoriented model (predominant in the US and AngloAmerican countries) and stakeholder-oriented model (predominant in Continental European countries). The rise of social proxy submissions in the US - along with other sustainable corporate initiatives ${ }^{144}$ - is changing the primacy of shareholder wealth maximization view within American boardrooms.

\subsection{Relevant Data}

Empirical data contains evidence that proposals addressing corporate social responsibility issues between 1998 and 2008 counted up to three in Continental Europe and 18 in the UK. ${ }^{145}$ For instance, in the UK most shareholders' proposals are focussed on proxy contests seeking board changes, whereas in Continental Europe they are more focussed on governance matters. There is a common element, however, being that most of the targeted companies seem to be underperforming. Moreover, when a vote occurs at the general meeting, it tends to have an adverse effect on the stock price. ${ }^{146}$ What is more concerning is that the voting results on social proposals are not being supported at shareholders' meeting.

For instance, in the UK, before submitting a proposal, a proponent is recommended to convince the rest of the shareholders of the topic wanted to be placed in the agenda of the next annual meeting, because it would be difficult to pass the resolution otherwise. ${ }^{147}$ Therefore, the lessons learned from the applicability of Rule14a-8 and its social contribution do not seem to be included in European jurisdictions. ${ }^{148}$

Notwithstanding, in the UK, the submission of shareholders' proposals is receiving more attention and is becoming notorious because of the support of some charities. ${ }^{149}$ According to Section 338 of the Companies Act 2006, shareholders in the UK may submit a propos-

143. Masouros 2010. Masouros adds that "the provision on shareholders' proposals is 'empty letter', because the five percent ownership threshold is still highly prohibitive, and shareholders are unable to communicate and form coalitions due to a lack of infrastructure for proxy solicitation and even access to share registries".

144. Other corporate initiatives in the US, like the Benefit Corporation legislation, is fostering changes for the benefit of stakeholders and the public interest.

145. Cziraki, Renneboog \& Szilagyi 2009.

146. Ibid.

147. Kershaw 2012.

148. Cziraki, Renneboog \& Szilagyi 2009.

149. Social proposals initiated by shareholders in the UK are as follows: 2007 Fair Pension Funds joint campaign with Oxfam medicines developing countries; in 2003, The New York City Pension Funds seeks to enforce Mac Bride principles in companies in Northern Ireland, based on the non-discrimination of Catholics in the Northern Ireland Irish Labour; oil companies BP and Shell faced shareholders' resolutions on their controversial Alberta Tar Sands projects. See more on $<$ http://shareaction $.0 \mathrm{rg} / \mathrm{P}$ al to be considered at the next annual general meeting, but only if the proponent represents not less than 5 percent of the total voting rights or if the proponent with less than the required threshold has the support of another 99 shareholders who have paid at least GBP100 per share. ${ }^{150}$ This eligibility requirement is considered extremely strict and difficult to achieve for individual investors, especially in comparison with the eligibility criteria under Rule $14 \mathrm{a}-8$ in the US. Thus, the chances in the UK to pass shareholder-initiated resolutions at the shareholders' meeting effectively are limited, resulting in the majority of proponents trying to pursue other alternatives. $^{151}$

\section{Conclusions}

Do shareholders have the power to pass shareholder-initiated social resolutions at the shareholders' meeting? When deciding about the significance of social policies in corporate law, the example of Lovenheim v. Iroquois Brands, Ltd. illustrates the (social) role of the American Securities Exchange Commission Rule 14a-8. The key element in that case entailed the court considering the proposal as eligible in the proxy statement of the company, because it could be demonstrated that it was significantly related to the firm's business, not in its economic context but in its social context. The proposal was related to a matter with little economic significance, as it did not comply with the 5 percent threshold requirement for eligibility. The social significance of the proxy proposal was clearly decisive in the court's opinion. Regardless of whether or not Peter Lovenheim was acting in the best interests of the company or in his own self-interest, the case confirmed the existence of a legitimate governance tool to incorporate and improve corporate social policies within American large public companies. Nowadays, directors should not underestimate shareholders' proposals even if they are precatory in nature. Moreover, they are a meaningful governance tool that enables shareholders to influence managerial decisions on the use of the company's assets in a more socially responsible manner.

\section{Bibliography}

B. Amann et al., "Shareholder Activism: US, Japan, France and Spain”, in D. McBarnet, A. Voiculescu \& T. Campbell (eds.), The New Corporate Accountability, Cambridge University Press, 2007, pp. 336-364.

I. Anabtawi \& L. Stout, "Fiduciary Duties for Activist Shareholders", 60 Stanford Lam Reviem, 2008, pp. 1255-1308.

J. Armour, H. Hansmann \& R. Kraakman, "What is Corporate Law?", in R. Kraakman et al. (eds.), The Anatomy of Corporate Law, A Comparative and Functional Approach, 2nd edn, Oxford University Press, 2009, pp. 1-33.

150. Section 153 Companies Act 2000.

151. Sandberg 2011 
S. Bainbridge, The Nem Corporate Governance in Theory and Practice, Oxford University Press, 2008.

S. Bainbridge, "Shareholder 14a-8 Proposals relating to Universal Health Care' in Stephen Bainbridge's", Fournal of Law, Politics, and Culture, 26 May 2008. Available at <www. professorbainbridge.com/professorbainbridgecom/2008/05/ shareholder-14a8-proposals-relating-to-universal-health-care. html > (last accessed 21 April 2015).

S. Bainbridge, "The Absurdity of the SEC's Shareholder Proposal Policy and Reform", Stephen Bainbridge's Journal of Law, Politics, and Culture, 19 February 2011. Available at <www. professorbainbridge.com/professorbainbridgecom/2011/02/ the-absurdity-of-the-secs-shareholder-proposal-policy-and-aproposed-reform.html> (last accessed 27 April 2014).

S. Bainbridge, "Preserving Director Primacy by Managing Shareholder Interventions", in J.G. Hill \& R.S. Thomas (eds.), Research Handbook on Shareholder Power and Activism, Edward Elgar Publishing Limited, 2015, pp. 231-248.

R. Bauer, F. Moers \& M. Viehs, "Who Withdraws Shareholders Proposals and Does It Matter? An Analysis of Sponsor Identity and Pay Practices", Corporate Governance: An International Reviem (Forthcoming), 2015. Available at <http://dx.doi.org/ $10.2139 /$ ssrn. $1885392>$.

L. Bebchuk, "The Case for Increasing Shareholder Power", 118 Harvard Lam Reviem 3, 2005, pp. 833-914.

L. Bebchuk, A. Brav \& W. Jiang, "The Long-Term Effects of Hedge Fund Activism", 2015, Harvard Law School John M. Olin Center Discussion Paper No. 802; 115 Columbia Law Reviem, 2015, pp. 1085-1156; Columbia Business School Research Paper No. 13-66.

A.A. Berle Jr., "For Whom Corporate Managers Are Trustees: A Note", 45 Harvard Lam Reviem, 1932, p. 1365.

A.A. Berle \& G.C. Means, The Modern Corporation and Private Property, New York, Macmillan, 1932.

A. Beyer, D.F. Larcker \& B. Tayan, Study on How Investment Horizon and Expectations of Shareholder Base Impact Corporate Decision-Making, National Investor Relations Institute and The Rock Center for Corporate Governance, 2014.

J.M. Bizjak \& C.J. Marquette, "Are Shareholder Proposals All Bark and No Bite? Evidence from Shareholder Resolutions to Rescind Poison Pills", 33 Fournal of Financial and Quantitative Analysis, 1998, pp. 499-521.

J.R. Branston, K. Cowling \& R. Sugden, "Corporate Governance and the Public Interest", International Reviem of Applied Economics, 2006, pp. 189-212.

R.E. Buckholz, M. Trevino \& H.L. Coleman, "Sullivan \& Cromwell LLP”, on Monday, 20 July 2015. Available at <http:// corpgov.law.harvard.edu/2015/07/20/third-circuit-provides -guidance-on-excluding-shareholder-proposals/ $>$.

J.C. Coffee Jr., J.H. Chopper \& R.J. Gilson, Cases and Materials on Corporations, Case Notes Legal Briefs, Business Organizations, 6th edn, Aspen Publishers, 2004, p. 93.

P. Cziraki, L. Renneboog \& P.G. Szilagyi, "Shareholder Activism through Proxy Proposals: The European Perspective", TILEC Discussion Paper No. 2009-019; ECGI - Finance Working Paper No. 252/2009, 16 December 2009.

A.A. Dhir, "Realigning the Corporate Building Blocks: Shareholder Proposals as a Vehicle for Achieving Corporate Social and Human Rights Accountability", 43 American Business Law Fournal 2, 2006, pp. 365-412.

E.M. Dodd, Jr., "For Whom Are Corporate Managers Trustees?", 45 Harvard Lam Reviem, 1932, pp. 1145-1163.

E. Elhauge, "Sacrificing Corporate Profits in the Public Interest", 80 NYU Lam Reviem, 2005.

Ernst \& Young Report, "Taking the Flight: Environmental Sustainability Proposals Gain More Attention", 2013. Available at $<$ www.ey.com/Publication/vwLUAssets/Environmental_
sustainability_proposals_gain_more_attention/\$FILE/Envi ronmentalSustainabilityGainAttention.pdf $>$.

Y. Ertimur, F. Ferri \& S.R. Stubben, "Board of Directors' Responsiveness to Shareholders: Evidence from Shareholder Proposals", Unpublished working paper, Harvard Business School, 2008.

L.M. Fairfaix, "Shareholder Democracy on Trial: International Perspective on the Effectiveness of Increased Shareholder Power", 1 Virginia Lam \& Business Reviem 1, 2008, p. 1.

P. Frentrop, "Short-Termism of Institutional Investors and the Double Agency Problem", 25 June 2012. Available at SSRN $<$ http://ssrn.com/abstract=2249872> or $<$ http://dx.doi. org/10.2139/ssrn.2249872>.

H.M. Friedman, Publicly Held Corporations: Lam and Practice, A Lamyer's Guide, Oxford University Press, 2011.

S.L. Gillan \& L.T. Starks, "Corporate Governance Proposals and Shareholder Activism: The Role of Institutional Investors", 57 Fournal of Financial Economics, 2000, p. 275.

C. Girard, Comparative Study of Successful French and Anglo-Saxon Shareholder Activism, unpublished working paper, Audiencia-Nantes School of Management, 2009.

H. Hansmann \& R. Kraakman, The End of History for Corporate Lam, Yale Law School Working Paper No. 235; NYU Working Paper No. 013; Harvard Law School Discussion Paper No. 280; Yale SOM Working Paper No. ICF - 00-09, January 2000. Available at SSRN <http://ssrn.com/abstract= 204528> or < http://dx.doi.org/10.2139/ssrn.204528>.

J. Harford, A. Kecskes \& S. Mansi, "Do Long-Term Investors Improve Corporate Decision Making?”, 18 April 2015, Finance Down Under 2015 Building on the Best from the Cellars of Finance Paper; Asian Finance Association 2015 Conference Paper. Available at SSRN <http://ssrn.com/ abstract $=2505261>$ or $<$ http://dx.doi.org/10.2139/ssrn. 2505261>.

S. Hirts, "Proxy Season 2011: A Tipping Point for Social and Environmental Issues?" in The Harvard Law School Forum on Corporate Governance and Financial Regulation, 18 September 2011. Available at <http://corpgov.law.harvard.edu/ 2011/09/18/proxy-season-2011-a-tipping-point-for-socialand-environmental-issues/ $>$.

D. Kershaw, Company Lam in Context, Oxford University Press, 2012.

D.E. Lazaroff, "Promoting Corporate Democracy and Social Responsibility: The Need to Reform the Federal Proxy Rules on Shareholders Proposals", 50 Rutgers Lam Reviem, 1997, p. 33.

I.B. Lee, "The Role of the Public Interest in Corporate Law", in C. Hill \& B. McDonnell (eds.), Research Handbook on the Economics of Corporate Lam, Palgrave, 2012.

D. Levit \& N. Malenko, "Nonbinding Voting for Shareholder Proposals", Journal of Finance, 37 Rock Center for Corporate Governance Working Paper, 2011, pp. 1579-1614.

M. Lipton, "Empiricism and Experience; Activism and ShortTermism; the Real World of Business", in The Columbia Lam School Blog on Corporations and Capital Markets, 2013. Available at <www.wlrk.com/webdocs/wlrknew/AttorneyPubs/ WLRK.22901.13.pdf>

M. Lipton, "The Threat to the Economy and Society from Activism and Short-Termism Updated, in Harvard Law School Forum on Corporate Governance and Financial Regulation, 22 January 2015. Available at <http://corpgov.law.harvard. edu/2015/01/27/the-threat-to-the-economy-and-societyfrom-activism-and-short-termism-updated $/>$ (last accessed 5 August 2015).

M. Lipton, "Dealing with Activist Hedge Funds", in Harvard Law School Forum on Corporate Governance and Financial Regulation, 5 August 2015. Available at <http://corpgov.law. 
harvard.edu/2015/06/02/dealing-with-activist-hedge-funds $-4 />$ (last accessed 8 August 2015).

H.G. Manne, "Shareholder Social Proposal Viewed by an Opponent", Stanford Law Reviem, 1971, p. 491.

K.J. Martin \& R.S. Thomas, "The Effect of Shareholder Proposals on Executive Compensation", 67 University of Cincinnati Lam Reviem, 1999, pp. 1021-1081.

P.E. Masouros, "Is the EU Taking Shareholder Rights Seriously? An Essay on the Impotence of Shareholdership in Corporate Europe”. 7 European Company Lam, 2010, pp. 195-203. Available at SSRN <http://ssrn.com/abstract $=1686725>$.

M. Mueller, "The Shareholder Proposal Rule: Cracker Barrel, Institutional Investors, and the 1998 Amendments", Stetson Law Reviem, 1998, pp. 452-515.

S. O'Brien, "The 1983 Amendments to SEC Rule 14A-8: Upsetting a Precarious Balance", 19 Valparaiso University Law Reviem 221, 1984.

J.E. Parkinson, Corporate Pomer and Responsibility, Oxford University Press, 1993.

L. Renneboog \& P.G. Szilagyi, "Shareholder Activism through the Proxy Process", ECGI - Finance Working Paper No. 275, 2010.

L. Renneboog \& P.G. Szilagyi, "The Role of Shareholder Proposals in Corporate Governance", Fournal of Corporate Finance, 2011, pp. 167-188.

L. Renneboog \& P.G. Szilagyi, "Shareholder Engagement at European General Meetings", in M. Belcredi \& G. Ferrarinid (eds.), Boards and Shareholders in European Listed Companies, Cambridge University Press, 2013.

B.J. Richardson, “Are Social Investors Influential?” 9 European Company Lam 2, 2012, pp. 133-140.

M. Rojas, et al., Bringing About Changes to Corporate Social Policy through Shareholder Activism; Filers, Issues, Targets and Success, Blackwell Publishing, 2009.

M.V. Sachs, "Social Proposals under Rule 14a-8: A Fall-Back Remedy in an Era of Congressional Inaction", 2 UC Irvine Law Reviem, 2012, pp. 931-944.

J. Sandberg, "Changing the World through Shareholder Activism", 5 Nordic Fournal of Applied Ethics 1, 2011, p. 51.

D.E. Schwartz, "Proxy Power and Social Goals - How Campaign GM Succeeded”, 45 St. Fohn's Lam Reviem 4, Article 9, 2012.

D.E. Schwartz \& E.J. Weiss, "An Assessment of the SEC Shareholder Proposal Rule”, 65 The Georgetomn Lam fournal, 1977, pp. 635-690.

J. Sherman \& A. Lehr, Human Rights Due Diligence: Is It Too Ris$k y$ ? Corporate Social Responsibility Initiative Working Paper No. 55. Cambridge, MA, John F. Kennedy School of Government, Harvard University, 2010.

L. Stout, The Shareholder Value Myth: How Putting Shareholders First Harms Investors, Corporations, and the Public, BerrettKoehler Publishers, 2012.

Sullivan \& Cromwell LLP, Report “... Excluding Shareholder Proposals: Trinity Wall Street v. Wal-Mart Stores, Inc.", 10 July 2015. Available at <www.sullcrom.com/siteFiles/ Publications/SC_Publication_Excluding_Shareholder_Pro posals_Trinity_Wall_Street_v_Wal_Mart_Stores_Inc.pdf $>$.

P. Sutherland, "Shareholder Democracy in South Africa?", in M. Olaerts \& C.A. Schwartz (eds.), Shareholder Democracy, An Analysis of Shareholder Involvement in Corporate Policies, Eleven International Publishing, 2011, pp. 79-102.

D.A.J. Telman, "Is the Quest for Corporate Responsibility a Wild Goose Chase? The Story of Lovenheim v. Iroquois Brands, Ltd.", 45 Akron Law Reviem, 2012, pp. 291-339.

R.S. Thomas \& J.F. Cotter, "Shareholder Proposals in the New Millennium: Shareholder Support, Board Response, and Market Reaction", 13 Journal of Corporate Finance, 2007, pp. 368391.
R.B. Thompson \& P.H. Edelman, "Corporate Voting”, 62 Vanderbilt Lam Reviem, 2009, p. 129.

P. Tkac, "One Proxy at a Time: Pursuing Social Change through Shareholder Proposals", Economic Review Third Quarter, Federal Reserve Bank of Atlanta, 2006.

B. Tricker, Corporate Governance: Principles, Policies and Practices, Oxford University Press, 2012. 